\title{
Nature of Virally Mediated Changes in Membrane Permeability to Small Molecules
}

\author{
Chaka C. IMPRAIM, Keith A. FOSTER, Kingsley J. MICKLEM and Charles A. PASTERNAK \\ Department of Biochemistry, St George's Hospital Medical School, Cranmer Terrace, \\ London SW71 ORE, U.K.
}

(Received 23 August 1979)

\begin{abstract}
1. The changes in membrane permeability to small molecules caused by Sendai virus [Pasternak \& Micklem (1973) J. Membr. Biol. 14, 293-303] have been further characterized. The uptake of substances that are concentrated within cells is inhibited. Choline and 2-deoxyglucose, which become phosphorylated, and aminoisobutyrate and glycine, which are driven by a $\mathrm{Na}^{+}-$linked mechanism, are examples. The uptake of each compound under conditions where its diffusion across the plasma membrane is rate-limiting is stimulated by virus. Choline, 2-deoxyglucose and amino acids at high concentration, amino acids in $\mathrm{Na}^{+}$-free medium, and most substances at low temperature, are examples. It is concluded that virally mediated decrease of uptake is due to one of two causes. Substances that are accumulated by phosphorylation are not retained because of leakage of the phosphorylated metabolites out of cells. Substances that are accumulated by linkage to a $\mathrm{Na}^{+}$gradient are no longer accumulated because of collapse of the gradient resulting from an increased permeability to $\mathrm{Na}^{+} .2$. Increased permeability to $\mathrm{K}^{+}$and $\mathrm{Na}^{+}$results in (a) membrane depolarization and (b) cell swelling. The latter event leads to haemolysis (for erythrocytes) and can lead to giant-cell (polykaryon) formation (for several cell types). 3. Recovery of cells can be temporarily achieved by the addition of $\mathrm{Ca}^{2+}$; permanent recovery requires incubation for some hours at $37^{\circ} \mathrm{C}$. 4 . The possible significance of virally mediated permeability changes, with regard to clinical situations and to cell biology, is discussed.
\end{abstract}

The initial event in viral attack, as well as the final stage in viral release, is an interaction with the cell surface. When paramyxoviruses such as Newcastle Disease virus (Klemperer, 1960b) or Sendai virus (Pasternak \& Micklem, 1973) are added to cells, leakage of intracellular constituents takes place. Leakage is not due to lysis, and is restricted to the passage of low-molecular-weight compounds and ions, i.e. to an increase in simple diffusion (Pasternak \& Micklem, 1973, 1974a). At the same time there is a decrease in the uptake of substances that become accumulated in cells following a facilitated transport mechanism. Virus thus appears to have an inverse effect on passive and facilitated uptake (Pasternak \& Micklem, 1974b). Initial attempts to separate the two effects proved unsuccessful (Pasternak et al., 1976), and it may be supposed that they are somehow linked. Here we show that a failure to retain accumulated compounds that enter by facilitated transport is not due to an effect on the uptake mechanism itself, but is a consequence of an increase in the permeability of cells.
An increase in simple diffusion of ions such as $\mathrm{K}^{+}$ (Klemperer, 1960b; Fuchs \& Giberman, 1973; Pasternak \& Micklem 1974a) and $\mathrm{Na}^{+}$(Poste \& Pasternak, 1978) is likely to result in membrane depolarization (Okada et al., 1975). The nature of this change is documented below. Another outcome is an entry of water, resulting in a swelling of cells (Knutton et al., 1976); we show here that this underlies not only the haemolytic action of paramyxoviruses, but also their capacity to mediate giant-cell (polykaryon) formation (Okada, 1958; Harris, 1970).

The effects of paramyxoviruses are prevented (Pasternak \& Micklem, 1974a), and can be reversed (Pasternak et al., 1976), by $\mathrm{Ca}^{2+}$. Some aspects of the nature of the recovery process are documented in the present paper.

\section{Materials and Methods}

Sendai virus was grown in 10-day-old embryonated eggs and harvested after 3 days ('3-day' virus) 
or after 1 day ('1-day' virus; Homma et al., 1976); unless otherwise stated, all virus was of the ' 3 -day' type. Occasionally virus grown for 3 days was found to have '1-day-like' character with respect to permeability changes and haemolysis; freezethawing, and dilution, of virus restored permeability changes and haemolysis. It is concluded that variables other than time of growth in eggs affects the capacity of Sendai virus to cause permeability changes. Haemagglutination units (HAU) of virus were determined by the method of Martin (1978).

Lettree cells were grown by serial passage in the peritoneal cavity of MF1 mice and harvested between 7 and 10 days. Cells were suspended in a solution containing $150 \mathrm{~mm}-\mathrm{NaCl}, 5 \mathrm{~mm}-\mathrm{KCl}$ and $5 \mathrm{~mm}$-Hepes [4-(2-hydroxyethyl)-1-piperazineethanesulphonic acid] buffer adjusted to $\mathrm{pH} 7.2$ with $\mathrm{NaOH}$ (' $\mathrm{Na}^{+}$medium') unless stated otherwise. ' $\mathrm{K}^{+}$ medium' contained $155 \mathrm{mM}-\mathrm{KCl}$ and $5 \mathrm{mM}$-Hepes buffer adjusted to $\mathrm{pH}$ 7.2.

Radioactive compounds used were $\left[\mathrm{U}^{-14} \mathrm{C}\right]$ adenosine (CFB 54), 2-amino $\left[1-{ }^{14} \mathrm{C}\right]$ isobutyric acid (CFA 203), $\left[\mathrm{Me}^{-14} \mathrm{C}\right]$ choline (CFA 424), 2-deoxyD- $\left[1-{ }^{3} \mathrm{H}\right]$ glucose (TRK 383), 3-O-methyl-D-[U- $\left.{ }^{14} \mathrm{C}\right]-$ glucose (CFB 141), [U-14 C]glycine (CFB 66), $\left[{ }^{3} \mathrm{H}\right]$ inulin (TRA 324), L-[4,5- $\left.{ }^{3} \mathrm{H}\right]$ leucine (TRK 170), methyl $\alpha$-D-[U- $\left.{ }^{14} \mathrm{C}\right]$ glucopyranoside (CFB 76), L$\left[3,4(\mathrm{n})-{ }^{3} \mathrm{H}\right]$ valine (TRK 533) and $\mathrm{L}-\left[\mathrm{U}-{ }^{14} \mathrm{C}\right]$ valine (CFB 75), all from The Radiochemical Centre, Amersham, Bucks., U.K., and $\left[\mathrm{Me}^{-}{ }^{3} \mathrm{H}\right]$ choline (NET 109) from New England Nuclear, Boston, MA, U.S.A. The concentrations to which cell suspensions were exposed were $1-2 \mu \mathrm{Ci}$ of ${ }^{3} \mathrm{H} / \mathrm{ml}$ and $0.1-0.2 \mu \mathrm{Ci}$ of ${ }^{14} \mathrm{C} / \mathrm{ml}$.

Permeability changes were assessed as follows. Leakage from pre-labelled cells was measured by the method of Pasternak \& Micklem (1973, 1974a). Uptake of labelled substrates was measured either by washing cells in ice-cold buffer or by spinning through oil (Impraim et al., 1979). The sample volume was $0.2 \mathrm{ml}$ in each case.

Phosphorylated metabolites of $\left[{ }^{3} \mathrm{H}\right]$ choline, 2deoxy $\left[{ }^{3} \mathrm{H}\right]$ glucose, $\left[{ }^{14} \mathrm{C}\right]$ adenosine and ${ }^{32} \mathrm{P}_{1}$ were measured as follows. Medium was separated from cells by spinning through oil, and cell pellets were suspended in water, sonicated at $20 \mathrm{kHz}$ and $15 \mathrm{~W}$ with a $3 \mathrm{~mm}$ probe for $30 \mathrm{~s}$ at $5^{\circ} \mathrm{C}$, and spun $(2700 \mathrm{~g}$-min) to obtain a water extract and residue. Alternatively cell pellets were extracted in $3 \%,(\mathrm{w} / \mathrm{v})$ $\mathrm{HClO}_{4}$ at $-5^{\circ} \mathrm{C}$, followed by centrifugation $(2700 \mathrm{~g}$ $\mathrm{min}$ ) and removal of $\mathrm{HClO}_{4}$ from the supernatant by precipitation with $\mathrm{KOH}$. Medium and water extract (or $\mathrm{HClO}_{4}$ extract) were analysed by paper chromatography [1 M-ammonium acetate $(\mathrm{pH} 5) /$ ethanol, $3: 7, \mathrm{v} / \mathrm{v}]$ or by ion-exchange chromatography on Polygram CEL 300 PEI (polyethyleneimine) sheets (Macherey Nagel and Co., 516 Duren, Germany) paper, with $3 \mathrm{M}-\mathrm{LiCl} / 1 \mathrm{M}$-acetic acid $(1: 9, \mathrm{v} / \mathrm{v})$ as solvent. Labelled material in the residue in $\left[{ }^{14} \mathrm{C}\right]-$ adenosine- and ${ }^{32} \mathrm{P}_{1}$-labelled cells was largely labelled RNA and DNA.

Membrane potential was assessed by the use of a fluorescent cationic dye (3,3'-dipropyloxadicarbocyanine), kindly given by Professor A. A. Eddy, as described by Philo \& Eddy (1978). The fluorescence intensity was measured with a Perkin Elmer MPF 44A spectrofluorimeter operated in the a.c. ratio mode to correct for lamp-output variations. Samples were excited at $580 \mathrm{~nm}$, bandwidth $5 \mathrm{~nm}$, and the emission was measured at $620 \mathrm{~nm}$, bandwidth $5 \mathrm{~nm}$, at $90^{\circ}$ to the excitation beam.

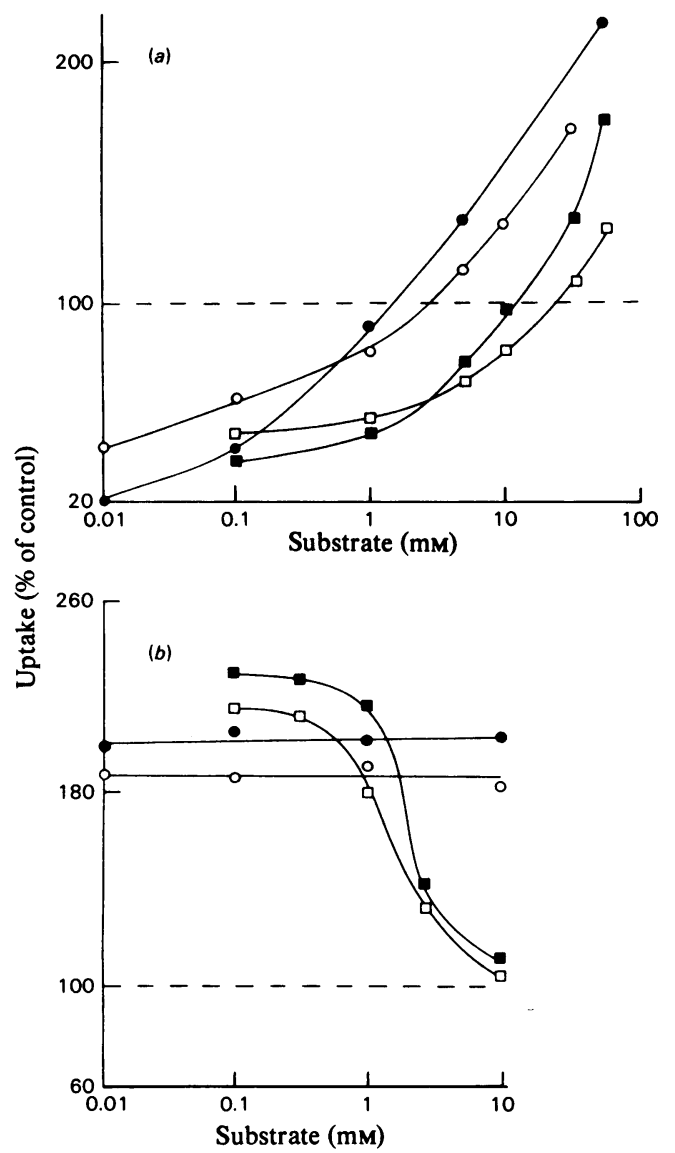

Fig. 1. Effect of virus on uptake of various substances Lettrée cells were incubated at $37^{\circ} \mathrm{C}$ with or without virus in the presence of radioactive substrates at the concentrations indicated, and uptake was assessed as described in the Materials and Methods section. Data from a number of different experiments are combined. (a) O, Choline; O, glycine; $\square$, aminoisobutyrate $\square$, 2-deoxyglucose; (b),$\alpha$-methyl glucoside; O, 3-O-methylglucose; $\square, \mathrm{Mn}^{2+} ; \square, \mathrm{Ca}^{2+}$. 


\section{Results and Discussion}

\section{Effect of virus on accumulation of substances that enter by facilitated transport}

Cells are able to accumulate sugars and other biosynthetic precursors present in extracellular fluid at low concentration by a facilitated uptake mechanism, followed by phosphorylation to yield a product that does not diffuse out of cells. In the case of amino acids, retention is achieved by coupling to the $\mathrm{Na}^{+}$gradient across cells (e.g. Christensen, 1975). When virus is added to cells, there is a decrease in the uptake of such substances. As the concentration of substrate is increased, a 'crossover point' is reached, beyond which the effect is reversed (Fig. 1a).

It thus seems that, at low concentration of substrate, virus causes a failure to retain accumulated substrate and its metabolites. In the case of choline and deoxyglucose, substrate entering Lettree cells is rapidly phosphorylated (Pasternak \& Micklem, 1973) so that after a brief exposure most is present as phosphocholine and 2-deoxyglucose 6-phosphate respectively (Table 1); further metabolism is minimal in either case. (Longer exposure to radioactive choline, of course, labels phospholipids and other products.) Note that virus does not affect the degree of phosphorylation of 2-deoxyglucose at $10 \mu \mathrm{M}$, despite a fall in intracellular ATP content, as documented below (Table 5). Since it is known that virus causes cells to become leaky to phosphorylated compounds (Pasternak \& Micklem, 1973, 1974a), the effect on uptake of substances at low concentration is likely to be due to this cause.

That this is indeed so, and that the effect of virus is not on the transport mechanism itself, receives support from two types of experiment. First, the data of Table 1 show that phosphorylated metabolites already appear in the medium during a $5 \mathrm{~min}$ 'uptake' pulse; moreover, the total amount of phosphorylated compounds (that in cells plus that in medium) is the same in the presence of virus as in its absence (Table 1). In other words, the total amount of choline or 2-deoxyglucose passing into the cell is the same; it is its subsequent fate that is modified by virus. Second, the effect of virus on the uptake of 3-O-methylglucose, which is taken up by facilitated transport but is not phosphorylated (Le Fevre, 1961), was measured. Fig. 1(b) shows that the effect of virus is to increase, not to decrease, uptake even at low concentration; in other words the effect is similar to that on a substrate such as $\alpha$-methyl glucoside (Pasternak \& Micklem, 1974b; Fig. 3) or bivalent cations (Impraim et al., 1979), which enter cells by passive diffusion alone (Fig. $1 b$ ). With bivalent cations, the viral effect is diminished at high concentration; this is because bivalent cations decrease virally induced permeability, including their own.

For amino acids at low concentration, the effect

Table 1. Effect of virus on phosphorylated metabolites of choline and 2-deoxyglucose Lettrée cells $\left(10^{8} / \mathrm{ml}\right)$ were exposed to labelled substrate with or without virus $(250 \mathrm{HAU} / \mathrm{ml})$ at $37^{\circ} \mathrm{C}$ for $5 \mathrm{~min}$, spun through oil, and the medium and cell pellet were analysed as described in the Materials and Methods section. The radioactivity in the medium at the start of incubation was as follows: $10 \mu \mathrm{M}$-choline, $1.9 \times 10^{6} \mathrm{c} . \mathrm{p} . \mathrm{m} . / \mathrm{ml}$; $20 \mathrm{~mm}$-choline, $1.9 \times 10^{6}$ c.p.m. $/ \mathrm{ml} ; 10 \mu \mathrm{M}$-deoxyglucose, $1.8 \times 10^{6}$ c.p.m. $/ \mathrm{ml} ; 20 \mathrm{~mm}$-deoxyglucose, $2.1 \times 10^{6} \mathrm{c} . \mathrm{p} . \mathrm{m} . / \mathrm{ml}$. The percentage distribution of radioisotope in the various cell fractions is shown.

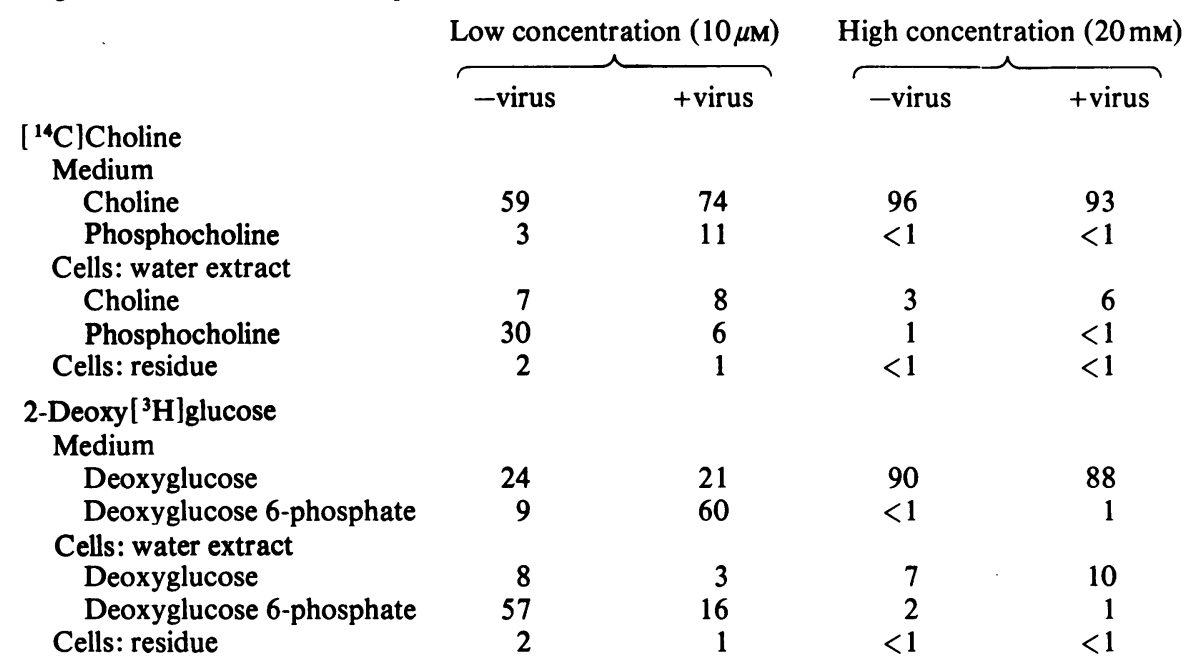


of virus is as shown in Table 2. That is, inhibition of uptake is in the order glycine and aminoisobutyrate $>$ valine and leucine. This is also the order in which amino acid uptake is linked to the $\mathrm{Na}^{+}$pump, as assessed by replacing $\mathrm{Na}^{+}$by $\mathrm{K}^{+}$in the incubation medium. The similarity between the effect of virus, and the degree of $\mathrm{Na}^{+}$linkage, is particularly clear-cut with glycine, as illustrated in Fig. 2. In other words, the effect of virus is not so much on the

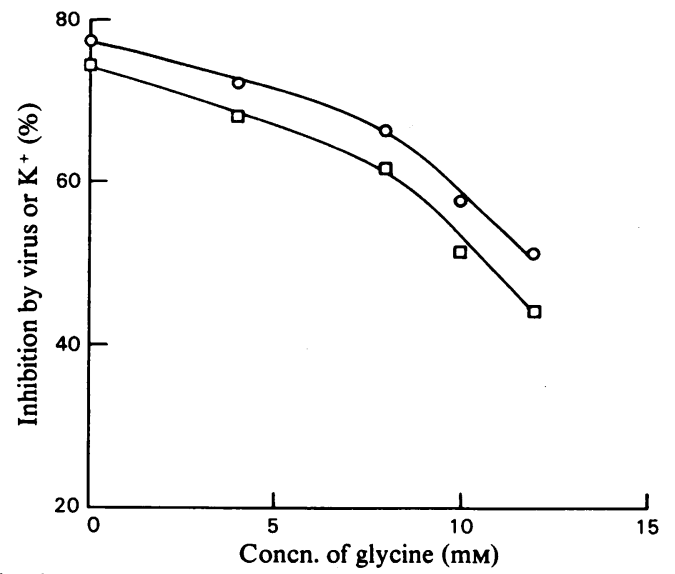

Fig. 2. Comparison between the effect of virus and of $\mathrm{Na}^{+}$ depletion on glycine uptake

Lettree cells were incubated for $12 \mathrm{~min}$ at $37^{\circ} \mathrm{C}$, with or without virus $(200 \mathrm{HAU} / \mathrm{ml})$ in $\mathrm{Na}^{+}$ medium, or in $\mathrm{K}^{+}$medium, with $\left[{ }^{14} \mathrm{C}\right]$ glycine at the concentrations indicated, and uptake was assessed by spinning through oil. The lowest concentration of glycine was $0.1 \mu \mathrm{M}$. $\square$, Percentage inhibition by virus; $O$, percentage inhibition by substituting $\mathrm{K}^{+}$ medium for $\mathrm{Na}^{+}$medium. uptake of the amino acid itself as on the $\mathrm{Na}^{+}$ gradient, which is abolished by virus (this is documented, in relation to membrane potential, more fully below); whether the inhibition of valine and leucine uptake at low concentration is due to some residual coupling mechanism or is the result of failure to retain accumulated leucine is not at present clear. The effect of virus on amino acid uptake is thus analogous to the action of uncoupling agents on $\mathrm{H}^{+}$-linked ATP synthesis in mitochondria: by making the membrane leaky, the ability to carry out ion-driven processes $\left(\mathrm{Na}^{+}\right.$-linked amino acid transport, or $\mathrm{H}^{+}$-linked ATP synthesis) is lost.

Choline uptake has been shown to be $\mathrm{Na}^{+}$-linked in nerve cells (Yamamura \& Snyder, 1972), and to be inhibited by conditions that cause membrane depolarization (Sen \& Cooper, 1978; Sen et al., 1978). Hence it is possible that the effect of virus on choline uptake is due to the abolition of the $\mathrm{Na}^{+}$ gradient, as well as to increased leakage of phosphocholine. However, in Lettrée cells, choline uptake is not $\mathrm{Na}^{+}$-linked; on the contrary choline uptake is increased in $\mathrm{K}^{+}\left(\mathrm{Na}^{+}\right.$-free) medium (Table 3). In other words, the effect of virus on choline uptake is due entirely to increased leakage of phosphocholine, and not to abolition of the $\mathrm{Na}^{+}$gradient.

The results presented above account satisfactorily for the observed decrease by virus in the extent of uptake of substances that accumulate in cells. Substances that do not accumulate in cells, or that enter by passive diffusion, are affected in the opposite way. In this case, the primary effect of virus is on rate, rather than extent; however, because virally treated cells swell (Knutton et al., 1976) [unless prevented from so doing by the presence of osmotically active substances in the medium, as illustrated below (Table 6)], an increase in extent of

Table 2. Effect of virus on uptake of amino acids

Lettrée cells $\left(4 \times 10^{7} / \mathrm{ml}\right)$ suspended in $\mathrm{Na}^{+}$or $\mathrm{K}^{+}$medium, were exposed to labelled amino acid with or without virus $(250 \mathrm{HAU} / \mathrm{ml})$ at $37^{\circ} \mathrm{C}$ for $10 \mathrm{~min}$, spun through oil and the radioactivity of the pellet was assayed. Low concentration was $1 \mu \mathrm{M}$; high concentration was $30 \mathrm{mM}$ (except for leucine, which was at $10 \mathrm{mM}$ ). The radioactivity in the medium at the start of incubation was as follows: $1 \mu \mathrm{M}$-glycine, $1.6 \times 10^{5} \mathrm{c} . \mathrm{p} . \mathrm{m} . / \mathrm{ml} ; 30 \mathrm{mM}$-glycine, $3.6 \times 10^{5}$ c.p.m. $/ \mathrm{ml} ; 1 \mu \mathrm{M}$-aminoisobutyrate, $2.0 \times 10^{5}$ c.p.m. $/ \mathrm{ml} ; 30 \mathrm{mM}$-aminoisobutyrate, $4.7 \times 10^{5} \mathrm{c.p.m} . / \mathrm{ml} ; 1 \mu \mathrm{M}$-valine, $1.5 \times 10^{5}$ c.p.m. $/ \mathrm{ml} ; 30 \mathrm{~mm}$-valine, $2.5 \times 10^{5}$ c.p.m. $/ \mathrm{ml} ; 1 \mu \mathrm{M}$-leucine, $3.0 \times 10^{5}$ c.p.m. $/ \mathrm{ml} ; 10 \mathrm{~mm}$-leucine, $3.1 \times$ $10^{5} \mathrm{c} . \mathrm{p} . \mathrm{m} . / \mathrm{ml}$. The values quoted are the percentage of the radioactivity in the medium that is taken by the cells.

\begin{tabular}{|c|c|c|c|c|c|c|c|c|}
\hline & \multicolumn{4}{|c|}{ Low concentration } & \multicolumn{4}{|c|}{ High concentration } \\
\hline & \multicolumn{2}{|c|}{$\mathrm{Na}^{+}$medium } & \multicolumn{2}{|c|}{$\mathrm{K}^{+}$medium } & \multicolumn{2}{|c|}{$\mathrm{Na}^{+}$medium } & \multicolumn{2}{|c|}{$\mathrm{K}^{+}$medium } \\
\hline & -virus & +virus & -virus & + virus & -virus & +virus & -virus & + virus \\
\hline$\left[{ }^{14} \mathrm{C}\right]$ Glycine & 33 & 5.1 & 4.2 & 4.5 & 4.4 & 4.0 & 1.8 & 3.8 \\
\hline Amino $\left[{ }^{14} \mathrm{C}\right]$ isobutyrate & 35 & 5.3 & 11 & 5.5 & 3.3 & 4.2 & 1.8 & 4.0 \\
\hline$\left[{ }^{3} \mathrm{H}\right]$ Valine & 21 & 7.4 & 22 & 5.0 & 4.6 & 4.6 & 1.9 & 4.0 \\
\hline$\left[{ }^{3} \mathrm{H}\right]$ Leucine & 24 & 6.7 & 25 & 5.3 & 3.5 & 4.2 & 2.4 & 4.4 \\
\hline
\end{tabular}


uptake, owing to an increase in intracellular volume. observed in addition to an increase in rate (see Fis. 1 of Pasternak \& Micklem, 1974b). ( $\alpha$-Methyl ducoside, which is neither phosphorylated nor taken up by a specific transport mechanism, is an example (Fig. 3); 3-O-methylglucose and bivalent cations behave similarly (Fig. 1b).

For the same reason, entry of choline, 2-deoxyducose or amino acids at high concentrations, when facilitated transport is saturated and has insufficient enpacity to bring the intracellular concentration up to that of the medium, is stimulated by virus (Fig. 1a and Tables 1 and 2; see also Pasternak \& Micklem. 1974b; Micklem \& Pasternak. 1977). In addition.

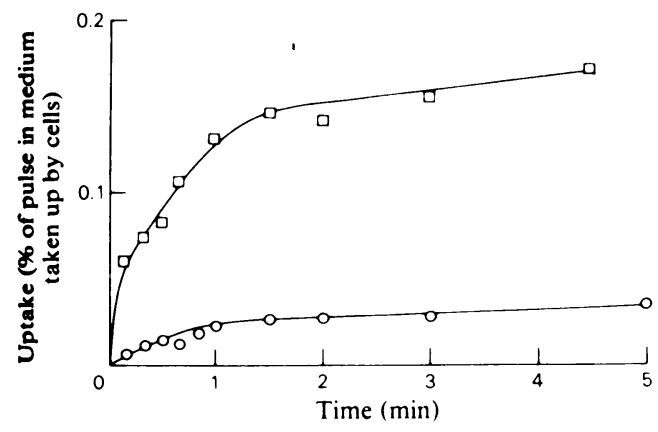

Fig. 3. Effect of virus on uptake of a-methyl glucoside Lettree cells were incubated at $22^{\circ} \mathrm{C}$ with or without virus $(250 \mathrm{HAU} / \mathrm{ml})$ in the presence of $10 \mathrm{~mm}$ a-methyl $\left[{ }^{14} \mathrm{C} /\right.$ glucoside, and uptake was assessed by spinning through oil. The values were corrected for the $\left[{ }^{3} \mathrm{H}\right.$ linulin space as described by Impraim et al. (1979). O. Uptake without virus: $\square$, uptake with virus. treatments that inhibit facilitated diffusion and thus make transport rate-limiting, such as $\mathrm{Na}^{+}$-free medium in the case of aminoisobutyrate and glycine (Table 2), or low temperature in the case of most substances (Table 3 ), show the same reversal of viral action. Thus the uptake at $5^{\circ} \mathrm{C}$ of glycine and aminoisobutyrate at low concentration is increased by virus: this is so despite the fact that uptake is still partially $\mathrm{Na}^{+}$-linked (values in parentheses in Table 3 ). For uptake of choline and 2-deoxyglucose at low concentration and low temperature, reversal of the viral effect is not complete (in contrast with the situation at high concentration, at either temperature); nevertheless, the inhibitory action of virus is much decreased (Table 3 ).

In summary, the data of Tables 2 and 3 show that the virally induced increase in simple diffusion leads to effective equilibration between the inside and outside of cells. That is, in the presence of virus, the uptake of most substances at any concentration is approx. 3-5\% of the amount present in the medium. This value presumably corresponds to the percentage intracellular water space of (virally swollen) Lettree cells at a concentration of $4 \times 10^{7} / \mathrm{ml}$. Higher percentage uptakes. which are generally seen only in the absence of virus, indicate a net accumulation. The above explanations of the inverse effects of virus are diagrammatically summarized in Fig. 4.

\section{Outcome of permeability' changes}

(a) Membrane depolarization. The membrane potential of cells may conveniently be assayed by the use of cyanine dyes (Waggoner, 1976). We have used 3.3'-dipropyloxadicarbocyanine, employing the methodology of Philo \& Eddy (1978), in which inhibitors are added to minimize effects owing to mitochondrial cation transport. In this system an

Table 3. Effect of temperature on virally mediated uptake changes

Lettree cells $\left(4 \times 10^{7} / \mathrm{ml}\right)$ in $\mathrm{Na}^{+}$medium were exposed to labelled substrate with or without virus $(250 \mathrm{HAU} / \mathrm{ml})$ at $37^{\circ} \mathrm{C}$ or $5^{\circ} \mathrm{C}$ for $10 \mathrm{~min}$. spun through oil and the radioactivity in the pellet was assayed. Low concentration was $1 \mu \mathrm{M}$; high concentration was $30 \mathrm{~mm}$. The radioactivity in the medium at the start of incubation was as follows: $1 \mu \mathrm{M}$-choline, $\quad 9.0 \times 10^{4} \mathrm{c} . \mathrm{p} . \mathrm{m} . / \mathrm{ml} ; \quad 30 \mathrm{~mm}$-choline. $9.6 \times 10^{4} \mathrm{c} . \mathrm{p} . \mathrm{m} . / \mathrm{ml}: \quad 1 \mu \mathrm{M}$-deoxyglucose. $\quad 1.2 \times 10^{5} \mathrm{c} . \mathrm{p} . \mathrm{m} . / \mathrm{ml}$ : $30 \mathrm{~mm}$-deoxyglucose. $2.0 \times 10^{5} \mathrm{c} . \mathrm{p} . \mathrm{m} . / \mathrm{ml}: 1 \mu \mathrm{M}$-glycine. $2.2 \times 10^{5} \mathrm{c} . \mathrm{p} . \mathrm{m} . / \mathrm{ml}: 30 \mathrm{~mm}$ glycine. $2.0 \times 10^{5} \mathrm{c} . \mathrm{p} . \mathrm{m} . / \mathrm{ml}: 1 \mu \mathrm{M}$ aminoisobutyrate. $1.5 \times 10^{5} \mathrm{c} . \mathrm{p} . \mathrm{m} . / \mathrm{ml} ; 30 \mathrm{~mm}$-aminoisobutyrate, $3.2 \times 10^{5} \mathrm{c} . \mathrm{p} . \mathrm{m} . / \mathrm{ml}$. The values quoted are the percentage of the radioactivity in the medium that is taken up by the cells. Values in parentheses refer to uptake in $\mathrm{K}^{+}$medium.

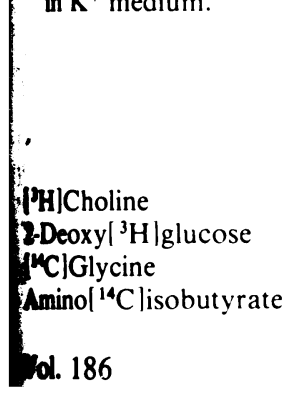

\section{Low concentration}

\begin{tabular}{|c|c|c|c|}
\hline \multicolumn{2}{|c|}{$37^{\circ} \mathrm{C}$} & \multicolumn{2}{|c|}{$5^{\circ} \mathrm{C}$} \\
\hline -virus & + virus & -virus & + virus \\
\hline $56(82)$ & $6.5(9.2)$ & 8.1 & 7.6 \\
\hline $65(77)$ & $13 \quad(14)$ & 45 & 11 \\
\hline $19(3.1)$ & $4.9(4.9)$ & $2.5(1.1)$ & $5.3(2.7)$ \\
\hline $31(12)$ & $4.7(6.1)$ & 2.2 & 5.3 \\
\hline
\end{tabular}

\begin{tabular}{|c|c|c|c|}
\hline \multicolumn{4}{|c|}{ High concentration } \\
\hline \multicolumn{2}{|c|}{$37^{\circ} \mathrm{C}$} & \multicolumn{2}{|c|}{$5^{\circ} \mathrm{C}$} \\
\hline -virus & + virus & -virus & +virus \\
\hline 2.7 & 5.4 & 2.3 & 6.8 \\
\hline 3.4 & 5.2 & 3.3 & 4.2 \\
\hline 6.1 & 3.9 & 0.8 & 5.0 \\
\hline 3.3 & 4.4 & 0.9 & 5.7 \\
\hline
\end{tabular}


(a) Substances accumulated by phosphorylation

(i) Low concentration: uptake by facilitated transport. Effect of virus: lower amount in cells, owing to leakage of metabolites.

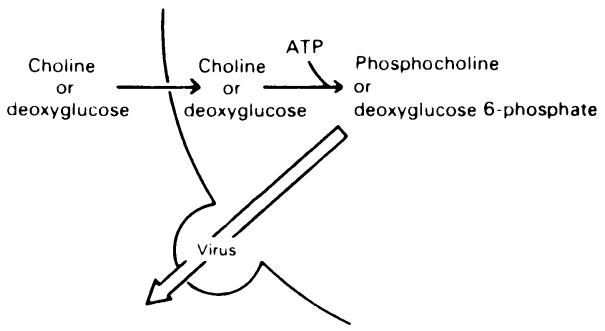

(ii) High concentration: uptake predominantly by simple diffusion.

Effect of virus: increased rate of entry (and exit); increased amount in cells owing to swelling.

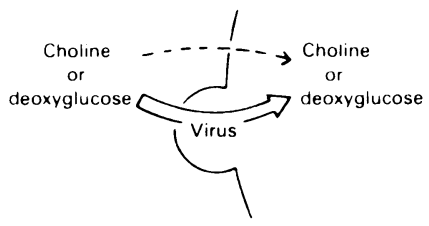

Note: dashed arrows indicate rate-limiting processes. The exit of substances has been omitted for clarity. The effects show are for $37^{\circ} \mathrm{C}$ : at $5^{\circ} \mathrm{C}$, the effect on substances at low concentration approaches that on substances at high concentration.

(b) Substances accumulated by linkage to $\mathrm{Na}^{+}$gradient

(i) Low concentration: uptake by facilitated mechanism (coupling to $\mathrm{Na}^{+}$gradient).

Effect of virus: lower amount in cells, owing to abolition of $\mathrm{Na}^{+}$gradient resulting from inward leakage of $\mathrm{Na}^{+}$.

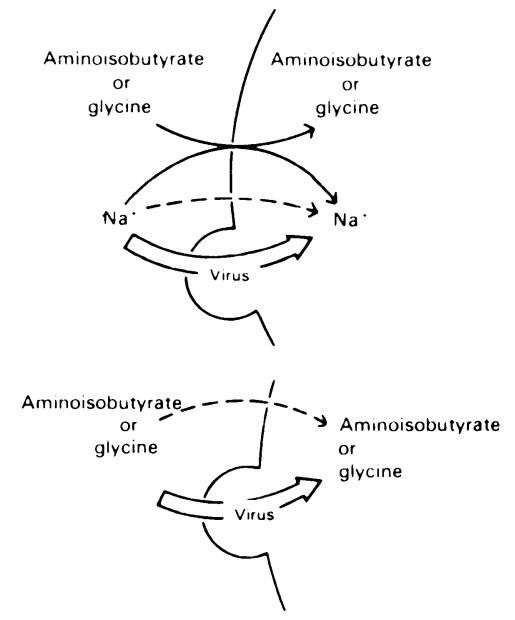

Note: dashed arrows indicate rate-limiting processes. The movement of substances, by exchange diffusion has been omittal for clarity. The effects shown are for $36^{\circ} \mathrm{C}$, in $\mathrm{Na}^{+}$medium: at $5{ }^{\circ} \mathrm{C}$, or in $\mathrm{K}^{+}$medium, the effect on substances at bor concentration resembles that on substances at high concentration.

Fig. 4. Summary of tiral effects on uptake of substances at low and high concentration

increase in fluorescence indicates a decrease in membrane potential. and vice versa. Thus $\mathrm{K}^{+}$added to cells results in an increase in fluorescence (depolarization), whereas valinomycin (in absence of $\mathrm{K}^{+}$) results in a decrease in fluorescence (hyper polarization) (Fig. 5).

When virus is added to cells at $37^{\circ} \mathrm{C}$. the fluorescence begins to increase within $30 \mathrm{~s}$, indicative of depolarization: the fact that fluorescence increases to an extent approximately equal to the fluorescence in the absence of the cells, and that subsequent addition of valinomycin (in presence $\mathrm{K}^{+}$) causes no further increase. suggests depolarization is virtually complete (i.e. the me brane potential is approximately zero). The effect temperature-dependent, is inhibited by $\mathrm{Ca}^{2+}$, resembles the permeability changes elicited by vin in other respects also (Table 4). The time at wh" $\mathrm{Ca}^{2+}$ is added is important: if added before, or than 1 min after, virus. depolarization is prevented added approx. 1 min after depolarization has beg. further depolarization is prevented and repole 


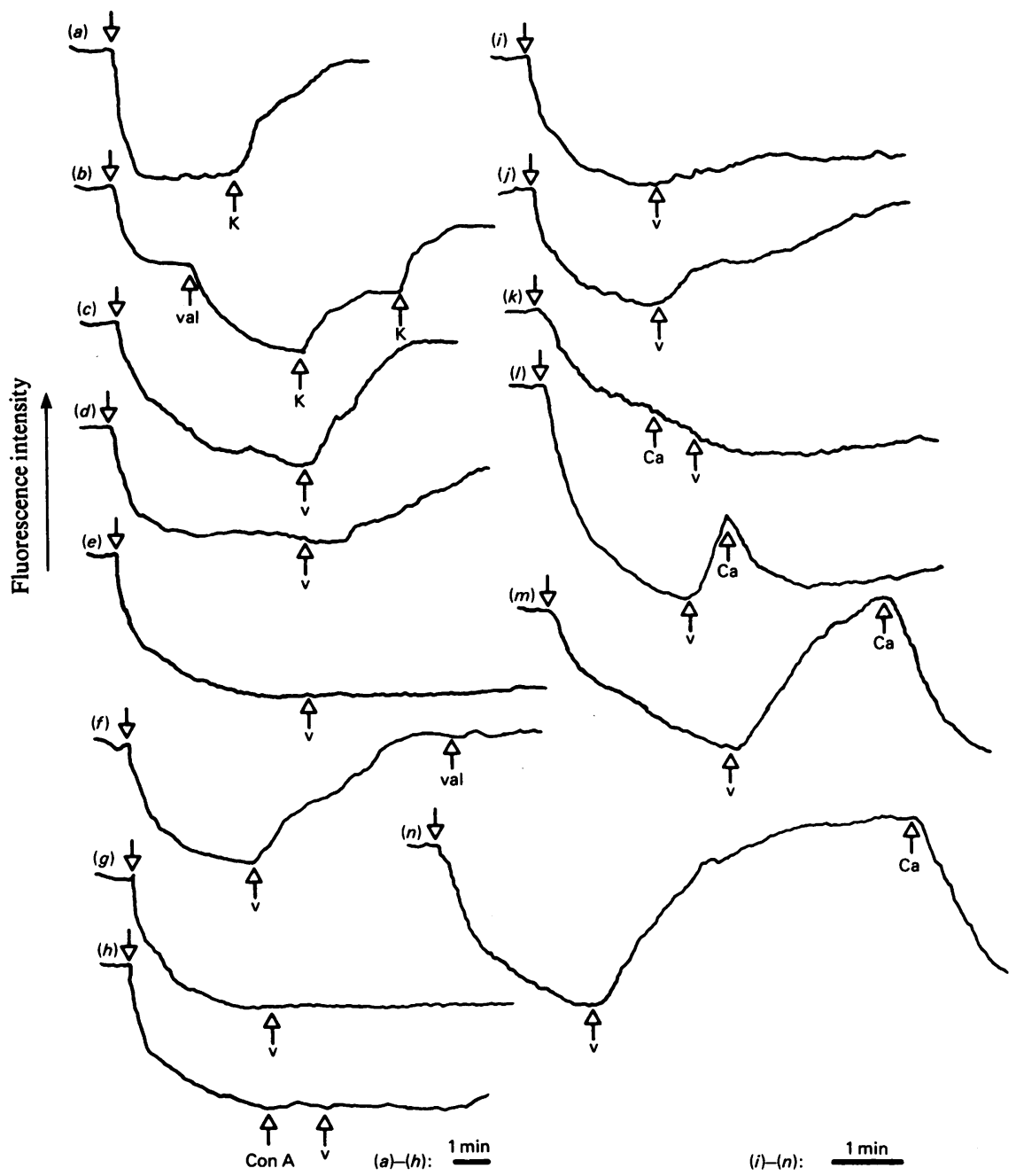

Fig. 5. Effect of virus on membrane potential

Lettree cells $\left(10^{7} / \mathrm{ml}\right)$ suspended in $\mathrm{Na}^{+}$medium were added to dye at the point indicated by $\frac{1}{2}$ and fluorescence intensity was measured as described in the Materials and Methods section. Concentrations of added substances refer to the final value. Measurements were made at $37^{\circ} \mathrm{C}$, except as indicated below. (a) $66 \mathrm{~mm}-\mathrm{KCl}(\mathrm{K})$ added as indicated. (b) Valinomycin (val; $13 \mu \mathrm{g} / \mathrm{ml}$ ) added as indicated, followed by $66 \mathrm{mM}$ - and $132 \mathrm{mM}-\mathrm{KCl}(\mathrm{K})$ at the times indicated. $(c)$ Virus $(\mathrm{v} ; 40 \mathrm{HAU} / \mathrm{ml})$ added as indicated. $(d)$ As $(c)$, but at $30^{\circ} \mathrm{C}$. $(e)$ As $(c)$, but at $20^{\circ} \mathrm{C}$. $(f)$ Virus (v; $40 \mathrm{HAU} / \mathrm{ml}$ ) added as indicated, followed by valinomycin (val; $13 \mu \mathrm{g} / \mathrm{ml}$ ). $(\mathrm{g})$ Heat-killed virus (v; originally $40 \mathrm{HAU} / \mathrm{ml}$ ) added as indicated. (h) Concanavalin A (Con A; $36 \mu \mathrm{g} / \mathrm{ml})$, followed by virus ( $\mathrm{v} ; 40 \mathrm{HAU} / \mathrm{ml}$ ), added as indicated. ( $(i)$ ' 1 -day' virus $(\mathrm{v} ; 30 \mathrm{HAU} / \mathrm{ml})$ added as indicated. $(j)$ ' 1 -day' virus after freezing and thawing 10 times $(\mathrm{v} ; 30 \mathrm{HAU} / \mathrm{ml})$ added as indicated. $(k)-(n) 5 \mathrm{mM}-\mathrm{CaCl}_{2}(\mathrm{Ca})$ and virus $(\mathrm{v} ; 40 \mathrm{HAU} / \mathrm{ml})$ added as indicated. Time scale is indicated by the bars.

\section{Table 4. Comparison between virally mediated permeability changes and membrane depolarization}

Permeability change

$>15-20^{\circ} \mathrm{C}$ (Pasternak \& Micklem, 1973)

Inhibition (Pasternak \& Micklem, 1974a)

Inhibition (Micklem \& Pasternak, 1977)

No change (Impraim et al., 1979)

Change initiated (C. C. Impraim \& C. A. Pasternak, unpublished work)
Membrane depolarization $>20^{\circ} \mathrm{C}$ (Fig. 5)

Inhibition (Fig. 5)

Inhibition (Fig. 5)

No change (Fig. 5)

Change initiated (Fig. 5)

Freeze-thawed '1-day' virus 
zation occurs. In other words the action of $\mathrm{Ca}^{2+}$ on permeability is instantaneous, in contrast with its action in re-establishing the $\mathrm{Na}^{+}$gradient, as reflected in aminoisobutyrate uptake (see Fig. 7 below), for example. The ouabain-sensitive $\left(\mathrm{Na}^{+}+\mathrm{K}^{+}\right)$ATPase, which is responsible for establishing and maintaining the gradient, is not itself affected by virus (Poste \& Pasternak, 1978); the supply of ATP, on the other hand, is (Table 5). Within $5 \mathrm{~min}$ of the addition of virus, for example, ATP concentrations have fallen by over $90 \%$; clearly the time taken to re-establish a net $\mathrm{Na}^{+}$ gradient reflects the time taken to replenish the ATP pool.

Note that virus causes a net loss of the intracellular adenine nucleotide pool in general, since AMP, like phosphocholine or 2-deoxyglucose 6-phosphate, leaks out of cells. ADP also appears to leak out of cells, but ATP does not (Table 5). It has, however, to be borne in mind that much of the ATP is likely to be mitochondrial, and it is the plasma membrane, not the mitochondrial membrane, that is modified by virus in the first instance. The reason for the loss of ATP is not clear. Presumably as ATP is used up to pump out $\mathrm{Na}^{+}$(unsuccessfully in the face of the increased permeability of cells), ADP so formed is converted back into ATP (and AMP) by adenylate kinase; the net result is a conversion of ATP and ADP into AMP, which leaks out. The decrease in $P_{1}$, through leakage out of cells (Table 5), may be another contributing factor to breakdown of adenine nucleotides (cf. Van den Berghe et al., 1977).

(b) Haemolysis. A characteristic feature of paramyxoviruses is their ability to cause haemolysis. Unlike bacterially mediated haemolysis, enzymes such as phospholipase A do not appear to be responsible, since phospholipid degradation is not observed during attack by paramyxoviruses (Pasternak \& Micklem, 1974a; Poste \& Pasternak, 1978). Nor is the action of neuraminidase (Klemperer, 1960a) likely to be responsible (Micklem \& Pasternak, 1977). Instead, haemolysis appears to result directly from virally mediated permeability changes; that is, the colloid osmotic pressure generated by the leakage of cations causes cells to

Table 5. Effect of virus on metabolites of adenosine and $P_{i}$

Lettree cells were incubated at $37^{\circ} \mathrm{C}$ with $\left[{ }^{14} \mathrm{C}\right]$ adenosine for $1 \mathrm{~h}$ or with ${ }^{32} \mathrm{P}_{1}$ for $30 \mathrm{~min}$, washed, resuspended $\left(2 \times 10^{8} / \mathrm{ml}\right)$ and incubated with or without virus $(150 \mathrm{HAU} / \mathrm{ml})$ at $37^{\circ} \mathrm{C}$ for $5 \mathrm{~min}$, spun through oil, and the medium and cell pellet were analysed as described in the Materials and Methods section. The percentage distribution of radioisotope in the various cell fractions is shown.

\begin{tabular}{|c|c|c|c|}
\hline \multirow[b]{2}{*}[{}^{[4}\mathrm{C}]{ Adenosine-labelled cells } & & \multicolumn{2}{|c|}{ Distribution (\%) } \\
\hline & & -virus & + virus \\
\hline Medium & $\begin{array}{c}\text { Adenosine } \\
\text { AMP } \\
\text { ADP } \\
\text { ATP }\end{array}$ & ) & $\begin{array}{r}1 \\
52 \\
3 \\
<1\end{array}$ \\
\hline Cells: water extract or $\mathrm{HClO}_{4}$-soluble & $\begin{array}{c}\text { Adenosine } \\
\text { AMP } \\
\text { ADP } \\
\text { ATP }\end{array}$ & $\begin{array}{r}4 \\
23 \\
13 \\
18\end{array}$ & $\begin{array}{r}1 \\
14 \\
6 \\
1\end{array}$ \\
\hline \multirow[t]{2}{*}{ Cells: residue or $\mathrm{HClO}_{4}$-insoluble } & & 35 & 22 \\
\hline & & \multicolumn{2}{|c|}{ Distribution (\%) } \\
\hline${ }^{32} \mathrm{P}_{1}$-labelled cells & Area* & -virus & +virus \\
\hline Medium & $\begin{array}{l}P_{1} \\
\text { AMP } \\
\text { ADP } \\
\text { ATP }\end{array}$ & $\begin{array}{l}20 \\
<0.2 \\
<0.2 \\
<0.2\end{array}$ & $\begin{array}{c}62 \\
1.5 \\
1.3 \\
0.5\end{array}$ \\
\hline Cells: $\mathrm{HClO}_{4}$-soluble & $\begin{array}{l}P_{1} \\
\text { AMP } \\
\text { ADP } \\
\text { ATP }\end{array}$ & $\begin{array}{l}56 \\
1.2 \\
1.1 \\
1.6\end{array}$ & $\begin{array}{c}10 \\
4 \\
0.6 \\
1.4\end{array}$ \\
\hline Cells: $\mathrm{HClO}_{4}$-insoluble & & 20 & 20 \\
\hline
\end{tabular}

* The distribution of ${ }^{32} \mathrm{P}$ in areas corresponding to $\mathrm{P}_{1}$, AMP, ADP and ATP markers is quoted, and includes any substances co-migrating with these markers. 
swell (Klemperer, 1960b). In the case of cells covered with microvilli or other protuberances, the latter can be 'unfolded' to give an increased volume (Knutton et al., 1976); in the case of erythrocytes, only a partial increase (from biconcave disc to sphere) is possible, beyond which lysis ensues. Thus erythrocytes leak haemoglobin and other proteins (Klemperer, 1960b), whereas villated cells retain their protein (Pasternak \& Micklem, 1973; Poste \& Pasternak, 1978) and remain impermeable to Trypan Blue (Pasternak \& Micklem, 1973). If haemolysis is indeed a direct consequence of permeability-induced osmotic swelling, then agents that $(a)$ inhibit the permeability change or (b) prevent osmotic swelling should abolish haemolysis. $\mathrm{Ca}^{2+}$, which has long been known to inhibit haemolysis (Burnet \& Lind, 1950; Fukai \& Suzuki, 1955; Sato, 1958; Klemperer, 1960b, Neurath, 1965), is an agent of the first category (Pasternak \& Micklem, 1974a); high concentrations of osmotically active substances such as glycerol, or substitution of $\mathrm{KCl}$ for $\mathrm{NaCl}$ as suspending medium, are agents of the second category. Both types of agent inhibit haemolysis (Table 6). Another reason for assuming that haemolysis is the direct outcome of permeability changes is the following. Homma et al. (1976) have shown the Sendai virus harvested after growth in embryonated eggs for 1 day instead of 3 days ('1-day' virus) is non-haemolytic, yet infective; freeze-thawing such virus renders it haemolytic. We confirm this observation and show (Table 6, and Impraim et al., 1979) that 1-day virus does not cause permeability changes, but that freeze-thawed 1-day virus does.

(c) Giant-cell (polykaryon) formation. A characteristic property of paramyxoviruses is their ability to cause cells to fuse together. That this property is, like haemolysis, a direct consequence of permeability-induced osmotic swelling is documented below. Note that we avoid use of the more usual term 'cell-cell fusion'. This is because cell-cell fusion has already occurred by stage 2 (Fig. 6), as shown by electron microscopy (Knutton, 1979), though by

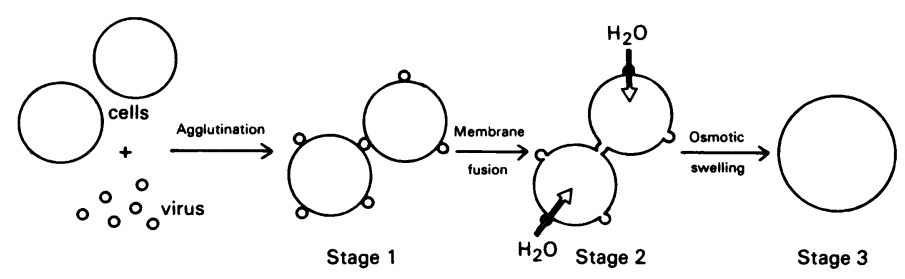

Fig. 6. Events leading to giant-cell (polykaryon)formation

For further details see the text.

Table 6. Inhibitors of haemolysis and giant-cell formation

A monolayer of human erythrocytes on collagen-coated plastic Petri dishes were exposed to virus (500 HAU/ml) and fusion index measured as described by Bachi et al. (1978); haemolysis was assessed by the $A_{540}$ of released haemoglobin. Lettrée cells were treated with virus and the volume, permeability change and fusion index measured as described by Knutton \& Pasternak (1979).

\begin{tabular}{|c|c|c|c|c|c|}
\hline \multirow[b]{2}{*}{ Treatment } & \multicolumn{2}{|c|}{ Erythrocytes } & \multicolumn{3}{|c|}{ Lettrée cells } \\
\hline & $\begin{array}{c}\text { Haemolysis } \\
\text { (\% of lysis by water) }\end{array}$ & Fusion index & $\begin{array}{l}\text { Volume } \\
\left(\mu \mathrm{m}^{3}\right)\end{array}$ & $\begin{array}{c}\text { Permeability } \\
\text { change } \\
\text { (\% leakage) }\end{array}$ & Fusion index \\
\hline None & $<1$ & $<0.01$ & 540 & 8 & $<0.001$ \\
\hline Virus & 98 & 0.4 & 780 & 80 & 0.6 \\
\hline Virus $+0.38 \mathrm{M}$-glucose & & & 540 & 75 & $<0.001$ \\
\hline $\mathrm{K}^{+}$medium + virus & 101 & $<0.01$ & 760 & 78 & $<0.001$ \\
\hline Virus $+1.2 \mathrm{M}$-glycerol & 42 & & & & \\
\hline Virus $+2.3 \mathrm{M}$-glycerol & 7 & $<0.01$ & & & \\
\hline Virus $+1 \mathrm{~mm}-\mathrm{CaCl}_{2}$ & 41 & & 730 & 55 & 0.6 \\
\hline Virus $+10 \mathrm{~mm}-\mathrm{CaCl}_{2}$ & 1 & $<0.01$ & 600 & 10 & \\
\hline '1-day' virus & 5 & 0.08 & & 15 & \\
\hline Freeze-thawed '1-day' virus & 90 & 0.4 & & 75 & \\
\hline
\end{tabular}

Vol. 186 
the criterion of light microscopy, used by other workers, cells at stage 2 appear 'unfused'.

Agents that prevent osmotic swelling, such as high concentrations of sugars or glycerol, or substitution of $\mathrm{KCl}$ for $\mathrm{NaCl}$ as suspending medium, prevent giant-cell formation (Table 6). Virally induced membrane permeability (as assessed by leakage of intracellular phosphorylated compounds) is not affected under these conditions, indicating that it is the net entry of water, consequent to a leakage of $\mathrm{Na}^{+}$and $\mathrm{K}^{+}$, that is required for giant-cell formation. Of course, if the change in permeability that is responsible for the abolition of the $\mathrm{Na}^{+} / \mathrm{K}^{+}$ asymmetry and the consequent entry of water is itself prevented, giant-cell formation does not occur either: the use of '1-day' virus instead of ' 3 -day' virus, or the presence of a high concentration of $\mathrm{Ca}^{2+}$, are examples (Table 6). Note that the concentration of $\mathrm{Ca}^{2+}$ necessary to prevent permeability changes is partly dependent on the amount of virus added; at low concentrations of cells and virus (at which agglutination, and hence giant-cell formation, does not occur) $0.1-0.5 \mathrm{mM}-\mathrm{Ca}^{2+}$ inhibits the permeability change by $50 \%$ (Pasternak \& Micklem, 1974a; Impraim et al., 1979). At the high concentrations of cells and virus required for cell-cell fusion, $1-2 \mathrm{mM}^{-} \mathrm{Ca}^{2+}$ is insufficient. In fact some $\mathrm{Ca}^{2+}$ is probably necessary for the formation and stability of fused cells, since EDTA prevents the process (Pasternak \& Micklem, 1974a).

The events leading to giant-cell formation may be summarized (Knutton \& Pasternak, 1979) as follows (Fig. 6). First, cells are brought close together by agglutination. This is temperature-independent, since it occurs at $0^{\circ} \mathrm{C}$ as well as at $37^{\circ} \mathrm{C}$. Next, the membranes between virus and cells fuse (virus-cell fusion); fusion requires a temperature greater than $15-20^{\circ} \mathrm{C}$ (Okada et al., 1975; see also Pasternak \& Micklem, 1973). Where a virus particle fuses simultaneously with two cells, a cytoplasmic bridge is formed (Apostolov \& Almeida, 1972; Knutton, 1978). Cells in this 'dumb-bell' shape then expand, as a result of osmotic swelling, to form a giant cell. The evidence that membrane fusion precedes swelling, that is, that stage 2 (Fig. 6) is a distinct entity, is two-fold. First, cells suspended in $\mathrm{KCl}$ do not form giant cells (Table 6); although such cells swell, they do so before the addition of virus; hence the 'driving force' for converting stage 2 into stage 3 is lost. Second, cells treated with '1-day' virus become arrested at stage 2 (Knutton, 1979), because '1-day' virus does not cause permeabiltiy changes; if such cells are exposed to hypoosmotic medium, giant-cell formation ensues (Knutton \& Pasternak, 1979).

\section{Recovery of cells}

The above has shown that changes that occur in the cytoplasm of cells exposed to Sendai virus can be ascribed to an increase in non-specific membrane permeability. Recovery of cells is dependent on restoration of the original permeability barrier. This can be achieved in one of two ways: by $\mathrm{Ca}^{2+}$, which temporarily restores the permeability barrier, and by incubation at $37^{\circ} \mathrm{C}$ in growth medium, during which time the surface membrane is gradually repaired.

The action of $\mathrm{Ca}^{2+}$ is almost instantaneous insofar as restoration of the permeability barrier to ions (Fig. 5), phosphorylated compounds (see Fig. 8), and other compounds that cross the plasma membrane by passive diffusion, is concerned (Fig. 7). Restoration of aminoisobutyrate uptake takes longer (over $70 \mathrm{~min}$ in the experiment illustrated in
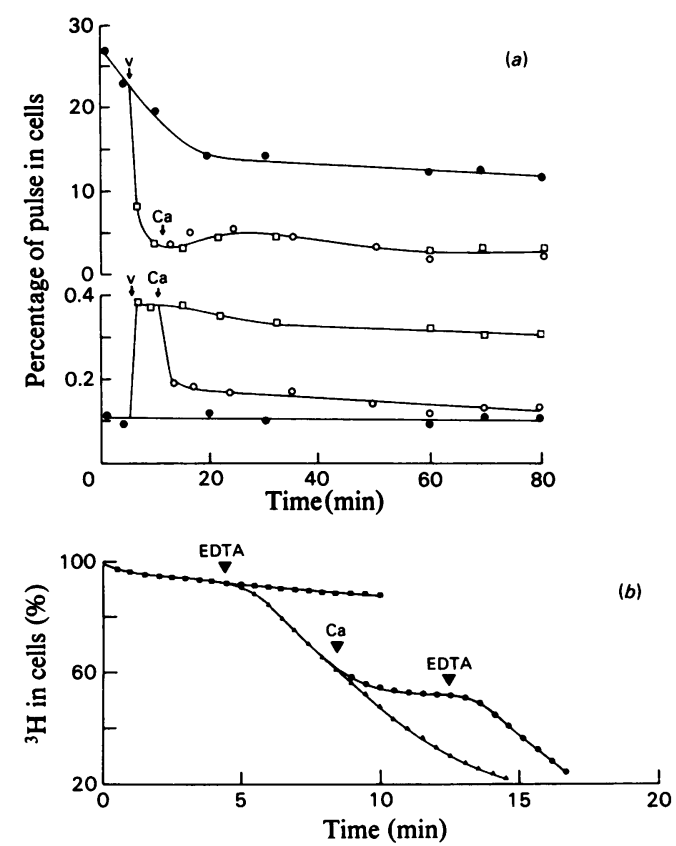

Fig. 7. Reversal of virally mediated changes by $\mathrm{Ca}^{2+}$ (a) Uptake of amino $\left[{ }^{14} \mathrm{C}\right]$ isobutyrate (upper graph) and $\left[{ }^{3} \mathrm{H}\right]$ choline (lower graph). Lettrée cells $\left(3 \times 10^{7} / \mathrm{ml}\right)$ were exposed to a $3 \mathrm{~min}$ pulse of $10 \mu \mathrm{M}$ amino $\left[{ }^{14} \mathrm{C}\right]$ isobutyrate and $20 \mathrm{~mm}-\left[{ }^{3} \mathrm{H}\right]$ choline at $37^{\circ} \mathrm{C}$ at the times indicated, and uptake was measured by spinning through oil. Virus $(20 \mathrm{HAU} / \mathrm{ml})$ and $\mathrm{CaCl}_{2}(5 \mathrm{mM})$ were added at the times indicated. $\bullet$, Without virus or $\mathrm{Ca}^{2+} ; \square$, with virus (v); $\mathrm{O}$, with virus plus $\mathrm{Ca}^{2+}(\mathrm{Ca})$. (b) Leakage of $\left[{ }^{3} \mathrm{H}\right]$ phosphocholine. Lettrée cells were incubated with $\left[{ }^{3} \mathrm{H}\right]$ choline, exposed to virus $\left(5 \times 10^{-5} \mathrm{HAU} / \mathrm{cell}\right)$ in the presence of $\mathrm{CaCl}_{2}$ $(0.5 \mathrm{mM})$, and release of ${ }^{3} \mathrm{H}$ was measured by the continuous-flow technique described by Impraim et al. (1979). $\square$, No additions; $\triangle$, EDTA (1 mM) added as indicated;, $\mathrm{CaCl}_{2}(0.5 \mathrm{mM})$ added as indicated; a further addition of EDTA ( $1 \mathrm{mM})$ was made as indicated. 
Fig. 7), presumably because restoration of the $\mathrm{Na}^{+}$ gradient, through operation of the $\mathrm{Na}^{+}$pump, takes time; restoration of the $\mathrm{Na}^{+}$gradient is insensitive to inhibition of protein synthesis. The observation that restoration of the membrane potential by $\mathrm{Ca}^{2+}$ is achieved within $1 \mathrm{~min}$ (Fig. 5) reflects the fact that membrane potential and $\mathrm{Na}^{+}$gradient are separate parameters: during a single depolarization of a neuron, for example, the overall $\mathrm{Na}^{+}$gradient is maintained despite reversal of the membrane potential, and conversely virally modified cells, in which the $\mathrm{Na}^{+}$gradient has been lost through equilibration between internal and external $\mathrm{Na}^{+}$, may yet show
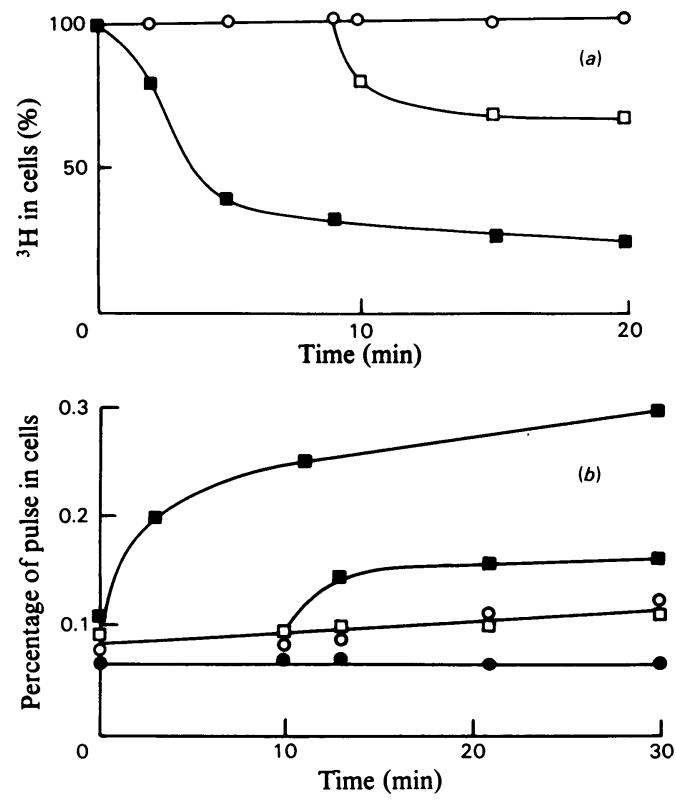

Fig. 8. Reversal of $\mathrm{Ca}^{2+}$-mediated recovery by EGTA (a) Leakage of phosphocholine. Lettrée cells were incubated with $\left[{ }^{3} \mathrm{H}\right]$ choline, washed and resuspended in medium containing $1 \mathrm{mM}-\mathrm{CaCl}_{2}$. Virus $(130 \mathrm{HAU} / \mathrm{ml})$ was added and cells were incubated at $37^{\circ} \mathrm{C}$. At 0 and $9 \mathrm{~min}$ after the start of incubation, a mixture of EGTA and $\mathrm{CaCl}_{2}$ was added to bring the concentration to $4.4 \mathrm{~mm}-\mathrm{EGTA}, 3.2 \mathrm{mM}-\mathrm{CaCl}_{2}$. Samples were analysed at intervals and the distribution of ${ }^{3} \mathrm{H}$ between cells and medium was assessed as described in the Materials and Methods section. O, No addition; $\square$ and $\square$, EGTA/ $\mathrm{CaCl}_{2}$ added at times indicated. (b) Uptake of $15 \mathrm{~mm}$ choline. Lettrée cells $\left(3 \times 10^{7} / \mathrm{ml}\right)$ were incubated with $15 \mathrm{~mm}-\left[{ }^{3} \mathrm{H}\right]$ choline with or without $6 \mathrm{~mm}-\mathrm{CaCl}_{2}$ (final concn.) and with or without virus $(250 \mathrm{HAU} / \mathrm{ml})$, and uptake was measured by spinning through oil. $O$, Without virus; $O$, without virus, in $6 \mathrm{mM}-\mathrm{Ca}^{2+} ; \square$, with virus, in $6 \mathrm{mM}^{-} \mathrm{Ca}^{2+} ; \square$, with virus, in $6 \mathrm{~mm}-\mathrm{Ca}^{2+}$, with EGTA $(14 \mathrm{mM})$ added at 0 or $10 \mathrm{~min}$ respectively. normal membrane potential [compare Fig. 7(a) with Fig. 5, traces $(l)-(n)]$.

Recovery of cells by the action of $\mathrm{Ca}^{2+}$ is temporary in the sense that, if the $\mathrm{Ca}^{2+}$ is subsequently removed by chelation with EGTA, the leaky nature of the cell membrane is partially restored (Figs. $7 b$ and 8 ); washing cells has the same effect. Recovery of cells by incubation at $37^{\circ} \mathrm{C}$ is permanent in the sense that the original permeability barrier is completely restored. Recovery takes about 2-4h for HeLa cells (Poste \& Pasternak, 1978). This probably reflects the turnover time of plasma membrane (Tweto \& Doyle, 1977); dispersion of viral components by diffusion in the plane of the membrane is quite rapid (Bachi et al., 1973) and therefore appears to be insufficient to restore the membrane to its normal state. Membrane turnover can occur through recycling of existing membrane and, like restoration of the $\mathrm{Na}^{+}$gradient, is insensitive to inhibitors of protein synthesis (J. Duncan, K. J. Micklem \& C. A. Pasternak, unpublished work). Recovery is temperature-dependent (see Table 2 of Impraim et al., 1979). If cells are kept at $4^{\circ} \mathrm{C}$, the viral effect is variable and depends on factors such as the original viral dose, the presence of $\mathrm{Ca}^{2+}$, the constituents of the medium, and so forth. What is clear is that at $37^{\circ} \mathrm{C}$ the maximum effect of virus can be quite short-lived. Fig. 9 shows this in the case of passive uptake of $\left[{ }^{3} \mathrm{H}\right]$ choline; leakage of $\left[{ }^{3} \mathrm{H}\right]$ choline metabolites is illustrated in Fig. 7 of Impraim et al. (1979).

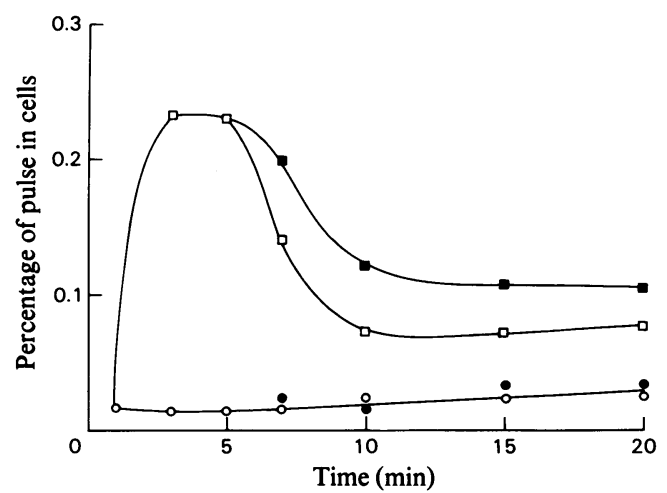

Fig. 9. Effect of temperature on duration of virally mediated permeability changes

Lettrée cells $\left(10^{8} / \mathrm{ml}\right)$ were incubated with or without virus $(500 \mathrm{HAU} / \mathrm{ml})$ for $5 \mathrm{~min}$ at $37^{\circ} \mathrm{C}$. They were then either maintained at $37^{\circ} \mathrm{C}$ or chilled to $5^{\circ} \mathrm{C}$. At the times indicated, suspensions were exposed to $20 \mathrm{~mm}-\left[{ }^{3} \mathrm{H}\right]$ choline for $3 \mathrm{~min}$ at $5^{\circ} \mathrm{C}$ and uptake was measured by washing in buffer. $\mathrm{O}$, Without virus, at $37^{\circ} \mathrm{C}$; 0 , without virus at $5^{\circ} \mathrm{C} ; \square$, with virus, at $37^{\circ} \mathrm{C}$; $\square$, with virus, at $5^{\circ} \mathrm{C}$. 


\section{Conclusion}

The results presented in this and in previous papers, and summarized by Knutton (1978), Poste \& Pasternak (1978) and Knutton \& Pasternak (1979), may be diagrammatically represented as shown in Fig. 10.

It is clear that the permeability changes are not a prerequisite for viral entry into cells. Any clinical significance is therefore not immediately obvious, especially as the changes are prevented by $\mathrm{Ca}^{2+}$ at concentrations of $\mathrm{Ca}^{2+}$ near those of plasma. Nevertheless virally mediated permeability changes may well contribute to the pathology of viral infections, for, at high virus concentrations, $2 \mathrm{mM}^{-}$ $\mathrm{Ca}^{2+}$ is ineffective at inhibiting the permeability change (Pasternak \& Micklem, 1974a); $2 \mathrm{mM}^{-\mathrm{Ca}^{2+}}$ is also ineffective at inhibiting the change in certain organ cultures (K. A. Foster \& C. A. Pasternak, unpublished work). In any case, the concentration of $\mathrm{Ca}^{2+}$ in interstitial fluid is less than that of plasma; also, fluctuation in $\mathrm{Ca}^{2+}$ concentrations may occur in certain disease states. Hence the possibility that permeability changes, especially with regard to $\mathrm{Na}^{+}$ and $\mathrm{K}^{+}$movements and membrane depolarization (Fig. 5), contribute to some of the consequences of viral infection such as encephalopathy (Illis, 1975) or intestinal disorders (Kerzner et al., 1977) warrants serious consideration.

So far as haemolysis (Table 6) is concerned, it is unlikely to be of much clinical relevance. Most types of haemolytic anaemia that are associated with viral infections are the result of an auto-immunity, rather than of a direct haemolytic effect of the virus (e.g. Dacie, 1963), though the generation of auto-antibodies possibly involves an initial haemolytic event. Destruction of blood platelets (thrombocytopenia), on the other hand, may be an outcome of direct viral action in a number of cases (Wintrobe, 1974); in this instance the underlying mechanism is not known.

Characterization of virally mediated changes is of importance in areas other than those of clinical medicine. The first relates to the properties of communicating ('gap') junctions, for the virally mediated permeability channel resembles that created by a communicating junction (Micklem \& Pasternak, 1977) in several regards. Phosphorylated compounds such as nucleotides and sugar phosphates, and ions such as $\mathrm{Na}^{+}$and $\mathrm{K}^{+}$, all of which leak only slightly out of cells under normal conditions, pass freely into the medium (virally modified cells) or from cell to cell (communicating junction). High-molecular-weight compounds, such as proteins or nucleic acids, do not pass through either type of channel (Pitts, 1976; Poste \& Pasternak, 1978). Each channel is 'closed' by $\mathrm{Ca}^{2+}$ (Rose \& Loewenstein, 1975; Pasternak \& Micklem, 1974a; Loewenstein, 1979). Virally induced channels may thus be considered as a kind of 'half' communicating junction. One difference between the two types of channel lies in the nature of the intramembrane particles revealed by freezefracture; virally induced channels show no obvious changes in intramembrane particles (Knutton, 1977), whereas in communicating junctions intramembrane particles form a distinct pattern of aggregates (Peracchia, 1977). Since the mechanism by which $\mathrm{Ca}^{2+}$ regulates the flow of compounds through communicating junctions is not yet clear, information about the action of $\mathrm{Ca}^{2+}$ in the rather simpler virus-cell system may prove to be of use.

The second situation concerns the permeability properties of transformed cells in culture. These show increased leakage of phosphorylated compounds (nucleotides and 2-deoxyglucose 6-phosphate) and of univalent cations such as $\mathrm{Rb}^{+}$(an analogue of $\mathrm{K}^{+}$) when external ATP is raised (Rozengurt et al., 1977), or internal ATP is lowered (Rozengurt \& Heppel, 1979); as in virally mediated permeability changes, the effect does not occur below $20^{\circ} \mathrm{C}$, and proteins such as lactate dehydrogenase do not leak out (Rozengurt et al., 1977). As yet, the effects of $\mathrm{Ca}^{2+}$ have not been fully studied in this situation, though there is an indication that it may be inhibitory to leakage

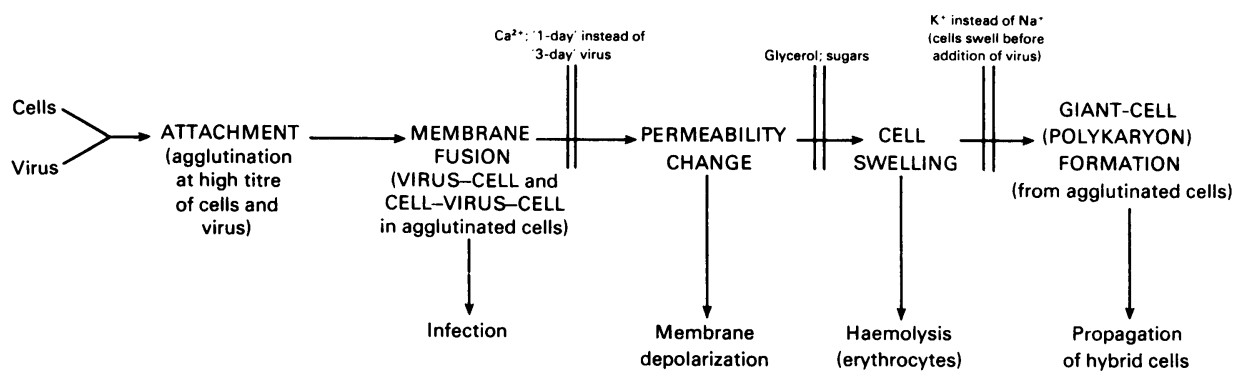

Fig. 10. Significance of virally mediated permeability changes

For further details see the text. 
Rozengurt et al., 1977), and this would certainly be expected by analogy with virally mediated changes. Since ATP concentrations fall rapidly after the addition of virus (Table 5), it may be wondered whether virally mediated changes are a consequence of such a decrease in cellular ATP. This is unlikely. First, virally mediated changes occur as well in 3T3 cells as in SV40/3T3 cells (Poste \& Pasternak, 1978), and this is not true of changes triggered by external ATP (Rozengurt et al., 1977). Second, all the characteristics of virally mediated changes suggest that the decrease in ATP is a consequence of increased permeability, not vice versa. On the contrary, it is possible that the inhibitors used by Rozengurt \& Heppel (1979) potentiate the permeability change by an action on the plasma membrane that is a cause (rather than a consequence) of the decrease in intracellular ATP.

Third, the effect of virus on the uptake of some amino acids confirms the electrogenic nature of that process. Just as the omission of $\mathrm{Na}^{+}$, or the addition of ouabain, gives an indication of the extent to which uptake is coupled to the movement of $\mathrm{Na}^{+}$, so does the addition of Sendai virus; because virus leads to an inverse effect on uptake of, for example, glycine in $\mathrm{Na}^{+}$or $\mathrm{K}^{+}$medium (Tables 2 and 3), electrogenic coupling is indicated in a particularly clear-cut way (Fig. 2). Moreover, with virus, $\mathrm{Na}^{+}$-dependence can be revealed in cells that are in contact with normal $\mathrm{Na}^{+}$medium. The effect on other amino acids, and indeed on other compounds, should prove rewarding in elucidating the extent to which the entry and accumulation of such compounds is linked to the $\mathrm{Na}^{+}$gradient.

Finally, the increased permeability induced in cultured cells by Sendai virus is useful for the introduction into cells of compounds that do not normally cross the plasma membrane. In studying the intracellular mechanism by which cellular growth is controlled, for example, it is desirable to be able to introduce cyclic nucleotides and other phosphorylated compounds. The exposure to a hyperosmotic medium (Castellot et al., 1978) and to lysophosphatidylcholine (Miller et al., 1979) have been suggested; Sendai virus (u.v.-inactivated to render it non-infectious) is a useful alternative. It too allows entry of phosphorylated compounds to take place and, as demonstrated in this paper, has the advantage that the extent and duration of the permeability change can be effectively controlled by $\mathrm{Ca}^{2+}$. Moreover the size of pore is probably smaller, since Trypan Blue is excluded (Pasternak \& Micklem, 1973), whereas it is taken up by the treatments of Castellot et al. (1978). The use of Sendai virus at exceptionally high virus : cell dose probably results in even bigger pores, and has been used to introduce macromolecules into cells (Tanaka et al., 1975; Yamaizumi et al., 1979).
We are grateful to the Science Research Council, Roche Products and the Ghana Atomic Energy Commission for financial support.

\section{References}

Apostolov, K. \& Almeida, J. D. (1972) J. Gen. Virol. 15, 227-234

Bachi, T., Aguet, M. \& Howe, C. (1973) J. Virol. 11, 1004-1012

Bachi, T., Eichenberger, G. \& Hauri, H. P. (1978) Virology 85, 518-530

Burnet, F. M. \& Lind, P. E. (1950) Aust. J. Exp. Biol. Med. Sci. 28, 129-150

Castellot, J. J., Miller, M. R. \& Pardee, A. B. (1978) Proc. Natl. Acad. Sci. U.S.A. 75, 351-355

Christensen, H. N. (1975) Curr. Top. Membr. Transp. 6, 227-258

Dacie, J. V. (1963) The Haemolytic Anaemias, 2nd edn., part II, p. 587, J. A. Churchill, London

Fuchs, P. \& Giberman, E. (1973) FEBS Lett. 31, $127-130$

Fukai, K. \& Suzuki, T. (1955) Med. J. Osaka Univ. 6, 1-15

Harris, H. (1970) Cell Fusion, Clarendon Press, Oxford

Homma, M., Shimizu, K., Shimizụ, Y. K. \& Ishida, N. (1976) Virology 71, 41-47

Illis, L. S. (1975) Viral Diseases of the Central Nervous System, Balliere-Tindall, London

Impraim, C. C., Micklem, K. J. \& Pasternak, C. A. (1979) Biochem. Pharmacol. 28, 1963-1969

Kerzner, B., Kelly, M. N., Gall, D. G., Butler, D. G. \& Hamilton, J. R. (1977) Gastroenterology 72, 457-462

Klemperer, H. G. (1960a) Virology 12, 495-498

Klemperer, H. G. (1960b) Virology 12, 540-552

Knutton, S. (1977) J. Cell Sci. 28, 189-210

Knutton, S. (1978) Micron 9, 133-154

Knutton, S. (1979) J. Cell Sci. 36, 85-96

Knutton, S. \& Pasternak, C. A. (1979) Trends Biochem. Sci. 4, 220-223

Knutton, S., Jackson, D., Graham, J. M., Micklem, K. J. \& Pasternak, C. A. (1976) Nature (London) 262, 52-54

Le Fevre, P. G. (1961) Pharmacol. Rev. 13, 39-70

Loewenstein, W. R. (1979) Biochim. Biophys. Acta 560, $1-65$

Martin, S. J. (1978) The Biochemistry of Viruses, p. 28, Cambridge Universtiy Press, Cambridge

Micklem, K. J. \& Pasternak, C. A. (1977) Biochem. J. 162, 405-410

Miller, M. R., Castellot, J. J. \& Pardee, A. B. (1979) Exp. Cell Res. 120, 421-425

Neurath, A. R. (1965) Acta Virol. (Engl. Ed.) 9, 119-129

Okada, Y. (1958) Biken's J. 1, 103-110

Okada, Y., Koseki, I., Kim, J., Maeda, Y., Hashimoto, T., Kanno, Y. \& Matsui, Y. (1975) Exp. Cell Res. 93, 368-378

Pasternak, C. A. \& Micklem, K. J. (1973) J. Membr. Biol. 14, 293-303

Pasternak, C. A. \& Micklem, K. J. (1974a) Biochem. J. $140,405-411$

Pasternak, C. A. \& Micklem, K. J. (1974b) Biochem. J. $144,593-595$ 
Pasternak, C. A., Strachan, E., Micklem, K. J. \& Duncan, J. (1976) in Cell Surfaces and Malignancy: Fogarty Int. Center Proc. 28 (Mora, P. ed.), pp. 147-151, U.S. Government Printing Office, Washington D.C.

Peracchia, C. (1977) Trends Biochem. Sci. 2, 26-31

Philo, R. D. \& Eddy, A. A. (1978) Biochem. J. 174, 801-810

Pitts, J. D. (1976) in Developmental Biology of Plants and Animals (Graham, C. F. \& Wareing, P. F., eds.), pp. 96-110, Blackwell Scientific Publications, Oxford

Poste, G. \& Pasternak, C. A. (1978) Cell Surf. Rev. 5, 306-349

Rose, B. \& Loewenstein, W. R. (1975) Nature (London) 254, 250-252

Rozengurt, E. \& Heppel, L. A. (1979) J. Biol. Chem. 254, 708-714

Rozengurt, E., Heppel, L. A. \& Friedburg, I. (1977) J. Biol. Chem. 252, 4584-4590
Sato, S. (1958) Virusu 8, 48-58

Sen, I. \& Cooper, J. R. (1978) J. Neurochem. 30, 1369-1375

Sen, I., Baba, A., Schulz, R. A. \& Cooper, J. R. (1978) J. Neurochem. 31, 969-976

Tanaka, K., Sekiguchi, M. \& Okada, Y. (1975) Proc. Natl. Acad. Sci. U.S.A. 72, 4071-4075

Tweto, J. \& Doyle, D. (1977) Cell Surf. Rev. 4, 137163

Van den Berghe, G., Bronfman, M., Vanneste, R. \& Hers, H. G. (1977) Biochem. J. 162, 601-609

Waggoner, A. (1976) J. Membr. Biol. 27, 317-334

Wintrobe, M. M. (1974) Clinical Haematology, 7th edn., p. 1101, Lea and Febiger, Philadelphia

Yamaizumi, M., Uchida, T. \& Okada, Y. (1979) Virology 95, 218-221

Yamamura, H. I. \& Snyder, S. H. (1972) Science 178, 626-628 